\title{
Research on College Students' Ideological and Political Education in the New Media Era
}

\author{
Mingfei Gong, Lili Zuo \\ Heilongjiang Bayi Agricultural University, Daqing, China \\ Email:1113162575@qq.com
}

How to cite this paper: Gong, M. F., \& Zuo, L. L. (2020). Research on College Students' Ideological and Political Education in the New Media Era. Creative Education, 11, 881-884.

https://doi.org/10.4236/ce.2020.116063

Received: April 12, 2019

Accepted: June 21, 2020

Published: June 24, 2020

Copyright (อ 2020 by author(s) and Scientific Research Publishing Inc. This work is licensed under the Creative Commons Attribution International License (CC BY 4.0).

http://creativecommons.org/licenses/by/4.0/

\begin{abstract}
In the era of new media, information technology integrates and develops continuously. Under the background of new media era, the pattern and path of ideological and political education of college students have undergone tremendous changes, which become a crucial study project in the domain of ideological and political education. This article focuses on the ideological and political education of college students in the new media era as the main research goal, studies the impact of the new media era on ideological and political education of college students, and explains the importance of ideological and political education, hoping to give some references for future educators.
\end{abstract}

\section{Keywords}

New Media, College Students, Ideological and Political Education

\section{Introduction}

With the continuous development of new media, people's thinking has also been affected to a certain extent. The globalization of information brings us many benefits and conveniences, but sometimes complicated information also brings certain influences and disadvantages to people's daily work, study and life, especially for college students. They have strong information collection ability and weak discernment, high external integration ability and low internal self-control ability. Under the background of complex and changeable social and spiritual environment in the new media era, the thinking of college students can be easily influenced by the outside complicated world, and poses higher challenges to ideological and political education. Therefore, it is necessary and crucial to carry out ideological and political education of college students in the era of new media. This article conducts in-depth research on ideological and political educa- 
tion of college students in the era of new media.

1) The impact of the new media era on college students' ideological and political education

a) The Internet age presents severe challenges to ideological and political educators

Our country has always regarded respect for teachers as an important traditional virtue. Teachers are respected in the eyes of students. Teachers have a fairly high right and status to speak in class and after class. Students usually pay close attention to class and trust the knowledge taught by teachers in their classes. Therefore, they form their own ideological and political thinking in the minds of college students. But with the advent of the Internet era, the way of college students to seek knowledge has not only been obtained from teachers, many students can seek the knowledge on the Internet in a timely manner. Due to the development of the Internet, college students in China are exposed to more foreign events, which has a certain degree of influence on the thinking of college students, including distrust of ideological and political teachers, which makes students have a certain degree of resistance to the ideas taught by teachers.

b) The conviction and influence of the content of university ideological and political education are weakened

$\mathrm{He}$ (2014) pointed out some issues in his book "Connotation and Influencing Factors of Effectiveness of Ideological and Political Education in Colleges and Universities." The political courses in university are constantly verified by many education experts, and through good ideological and political education, college students can get better political thinking. However, at this stage, the knowledge and information of college students have not only come from their own teachers, but also ingested from the Internet. Many students are convinced of the information on the Internet. This situation has caused college students to seriously affect the knowledge taught by teachers, and the effect of their courses is greatly weakened. At the same time, it also wastes the time and energy of students as well as teachers.

c) The Internet era has hit traditional teaching methods

Nowadays, ideological and political teachers in our country pay more attention to the traditional teaching model. In the traditional teaching mode, ideological and political teachers can conduct simple narration, thereby saving teachers' lesson preparation time. However, after receiving the influence of the Internet, there will be some changes in students' thinking. The teacher-directed teaching style made students feel bored, and then there was resistance in students' mind. In the development of the Internet era, teachers should change the traditional one-way teaching model, and should continue to innovate teaching methods, so that students are interested and willing to learn, so as to learn ideological and political content better.

2) The importance of ideological and political education of college students in the new media era

Firstly, let college students' ideology and politics adapt to a more open cultur- 
al environment. China's education system and environment are completely different from foreign countries. In our society, students receive nine years of compulsory teaching, and students complete knowledge learning at school, which results in less social experience and a single cultural environment. Therefore, students feel fresh when they come into contact with the Internet, but because they do not have rich social experience, they cannot distinguish the information on the Internet very well. When students enter the university, they are separated from their parents, and students spend more time on the Internet. Therefore, college students must receive ideological and political education to ensure a good three views (world view, valuable view and life view).

Secondly, the comprehensive personality of college students should be cultivated. When college students enter the society in search of work, employers value the personality of students, and their personality is an important indicator for evaluating a person. As the important high-quality talents for the development of our country, college students need to have a comprehensive personality. Not only do they have basic cultural accomplishments, but also excellent ideological and political ethics. In recent years, there are many students who graduated from prestigious universities in China, but their ideological and political literacy is poor, which has a serious negative impact on the country. Therefore, it is more important to enhance the ideological and political education of college students.

3) Countermeasures and suggestions for college students' ideological and political education in the new media era

a) The teacher's traditional concept and the method of preparing lessons should be changed

Sun (2016) pointed out some issues in his book "Research on the Innovation of Ideological and Political Education in Universities under the Internet Era." In China's social system, teachers often use traditional teaching models to directly teach their knowledge in the curriculum. However, in the traditional educational model, students will feel too monotonous or bored, and then appear to be in conflict. In the current Internet situation, teachers should also change their thinking and teaching methods, prepare lessons for students from the perspective of interest, and then mobilize the enthusiasm of students to listen to classes, so that students no longer have resistance to the classroom.

b) Teaching methods should be innovated and internet teaching platform should be built

Ideological and political education is a relatively long task. While students are studying ideological and political courses, they can shape the correct ideas well. Yang (2016), in his book named "Re-recognition and development trend of learning resources in the era of 'Internet+'," believes that in the classroom, Therefore, in the teaching of content, teachers should make certain innovations and use the Internet to teach, for example, through various social platforms, WeChat, Weibo, etc., teachers allow students to learn on platforms of interest, but also they have more opportunities for communication and interaction. Stu- 
dents are interested in ideological and political education in the interaction, and then students' ideological development direction should be guided.

c) An excellent faculty should be built

Teachers as social pioneers, are a very important factor in ideological and political education, which requires teachers to have a relatively high comprehensive quality. When teaching in the spare time, teachers cannot follow the traditional teaching mode in the past, and should actively innovate methods to understand students' inner thoughts, thereby changing their teaching methods. But in actual teaching, there is a shortage of excellent teachers in China. Therefore, in the recruitment of teachers, colleges and universities should focus on the quality of teachers, innovation awareness, and Internet teaching ability. At the same time, during the school period, colleges and universities should organize teachers for Internet training, so that teachers can also update Internet knowledge in a timely manner.

\section{Conclusion}

The rapid development of the Internet has provided more and more opportunities as well as benefits for economic development, and it has also brought some negative impacts on society. The development of the Internet allows people to understand the global culture without leaving home. Under the influence of the Internet, college students should keep their thoughts clearly and choose the culture and information they accept. Only in this way can talents become beneficial to the country. As an important pillar of China's future development, college students should have good ideological and political qualities, so as to enable our country to develop continuously and efficiently in the future. Therefore, the ideological and political education of college students in the new media era is particularly important.

\section{Conflicts of Interest}

The authors declare no conflicts of interest regarding the publication of this paper.

\section{References}

He, G. M. (2014). Connotation and Influencing Factors of Effectiveness of Ideological and Political Education in Colleges and Universities. School Party Building and Ideological Education, No. 16, 14-16.

Sun, F., \& Zhao, P. (2016). Research on the Innovation of Ideological and Political Education in Universities under the Internet Era. Journal of Shanxi University of Finance and Economics, No. 11, 111-112.

Yang, X. M., \& Zhao, X. S. (2016). Re-Recognition and Development Trend of Learning Resources in the Era of "Internet+". No. 10, 88-96. 